\title{
Insight
}

ChINA \& WTO ReV. 2019:1; 207-214

http://dx.doi.org/10.14330/cwr.2019.5.1.11

pISSN 2383-8221 • elSSN 2384-4388

China and WTO Review

\section{Is Huawei a Leverage of the US-China Trade War? A Critical Reflection on the Huawei Case}

\author{
Xiaohan Zhang ${ }^{*}$ \\ Zhejiang University School of Law
}

On January 28, 2019, the US Department of Justice announced criminal charges against Huawei. A pair of indictments accusing Huawei of violating the US sanctions as well as stealing trade secrets was unsealed in two separate cases. In fact, as a technology-intensive enterprise, Huawei has always been under close scrutiny from the US government for 'national security' concerns, and both the criminal allegations have existed for years. The Chinese side questioned the American motives, accusing that the US is actually using law enforcement as one tool among many to achieve its policy objectives in the Huawei case. The article presents the Chinese side of the case as well as the grounds for its position.

Keywords: Huawei, US Sanctions, Trade Secrets, National Security

On January 28, 2019, the US Department of Justice charged Huawei with violating the US sanctions against sales to Iran as well as stealing trade secrets from T-Mobile, its US partner. ${ }^{1}$ The charges of theft of trade secrets relate to Huawei's alleged attempts to steal the technology used by T-Mobile in a robot called Tappy, which was designed to test the performance of mobile devices, while those of sanctions violations relate to Huawei's affiliation with a company called Skycom, which was reported to have offered to sell embargoed equipment to Iran in 2013.

According to the indictment unsealed in federal court in Brooklyn, the investigation into Huawei's violations of the US sanctions can be traced back to 2007 . $^{2}$ However, the charge of Huawei's trade secrets theft is old news, stemming

* Postdoctoral Fellow at Zhejiang University, China. LL.B./LL.M. (Zhejiang Univ.), Ph.D. (HKU). The author may be contacted at: hkuzhangxiaohan@qq.com/Address: Zhejiang University Zhijiang Campus, 51 Zhijiang Road, Xihu District, Hangzhou, Zhejiang, P.R. China 31008. 
from a civil lawsuit filed by T-Mobile in 2014. It actually ended with Huawei paying USD 4.8 million to T-Mobile for breaching a "Handset Accessory Supply Agreement." At that time, as the Seattle jury found no "willful and malicious" misappropriation in Huawei's conduct, it did not award any damages for theft of trade secrets. $^{3}$

This shows that the sanctions allegations have existed for years, while the Tappy allegations have already been settled. Yet, both began to come to a head when the Trump administration dramatically announced the criminal charges against Huawei on January 28. This action has at least two possible interpretations. On the one hand, since the US government has long been accusing Chinese companies of stealing trade secrets and patented technology from American companies, that American side may have reached a breaking point. On the other hand, since the US government has been looking for ways to curb Huawei's growth in the West, this case could be a good pretext for doing so.

In fact, as technology-intensive enterprises, Chinese telecom companies such as Huawei and ZTE have always been under close scrutiny from the US government for 'national security' concerns. Current Huawei issues would be due to its perceived ties to the Chinese government. Its founder, Mr. Zhengfei Ren, once served as an engineer with China's People's Liberation Army. His leadership style is low-profile. Since Huawei was established in 1987, Mr. Ren has given no more than 10 interviews. ${ }^{4}$ Moreover, he rejected the idea of Huawei going public, even though the company would have received a warm welcome from the markets. In traditional Chinese culture, such a style is said to follow the "Doctrine of the Golden Middle Way" [中庸之道], which is considered commendable. In contrast, to Westerners, such an 'opaque' business model inevitably attracts suspicion, leading to the idea that Huawei might be beholden to the Chinese government, despite the lack of any evidence. ${ }^{5}$

Huawei is trying its best to clarify its position. Mr. Ren insists that Huawei has complied with all national regulations wherever it operates and the Chinese government has never asked Huawei for data, which would be 'definitely' refused if it did so. ${ }^{6}$ He also mentioned that the West generally thinks there is ideology printed on Huawei equipment. He refuted: "That is as stupid as smashing textile machines during the industrial revolution." He further commented: "Huawei only provides equipment run and controlled by its operators, not by Huawei 
itself." ${ }^{8}$ Such statements have proven futile. Although no evidence has emerged to support the fear of the company so far, ${ }^{9}$ the US congress has already proposed blocking Huawei from government contracts and advised carriers, ISPs and even private citizens against buying its products. ${ }^{10}$ In addition, the US government secretly pressed allies last year to join forces to stop Huawei from participating in constructing global $5 \mathrm{G}$ networks. ${ }^{11}$

However, as of January 2019, the US officials have not put forward any factual evidence linking Huawei to spying. Furthermore, they risk being accused of having double standards. As the whistleblower Edward Snowden revealed, American technology companies have been prepared to work with the US spy agencies. ${ }^{12}$ In other words, the Americans are actually trying to do the exact things they are worried Huawei will do to the US.

The US hostility combined with its lack of hard evidence have prompted some countries to "question whether America's campaign is really about national security, or if it is aimed at preventing China from gaining a competitive edge." 13 It is worth noting that Huawei has been developing at an exceptionally fast pace in recent years. In the second quarter of 2018, Huawei overtook Apple to become the world's second-largest smartphone seller behind Samsung, the first time in seven years that any contender has managed to enter the top two. ${ }^{14}$ More importantly, Huawei has become a major player in $5 \mathrm{G}$, a field in which, the Trump administration thinks, the dominant country will gain an economic, intelligence and military edge over its competitors. ${ }^{15}$

Given this background, China believes that the US is actually using law enforcement as one tool among many to achieve its policy objectives in the Huawei case. Shuang Geng, the spokesman for the Chinese Ministry of Foreign Affairs said: "A country has the right to safeguard its information security. But it cannot, under the pretext of security, harm or even stifle the legitimate operation of enterprises." ${ }^{16}$ Furthermore, China has "urged the US to stop its unjustified crackdown on Huawei, and provide a fair environment for mutual investment and cooperation."17

China's arguments seem not unreasonable. Huawei might have exported goods or technologies to Iran via several multinational banks that operated subsidiaries in the US. Although it might have violated the US sanctions, ${ }^{18}$ there is always such a thing as prosecutorial discretion, even in less ambiguous cases. Under the 
American law, not every case will be prosecuted, since prosecuting attorneys have nearly absolute power to choose which cases to bring to trial. Samsung, for instance, is one of Iran's largest mobile-phone suppliers, ${ }^{19}$ while the Swedish telecom company Ericsson has been selling equipment to Iran regardless of the sanctions. ${ }^{20}$ Due to the complexity of global component sourcing, it is unlikely that even American products or intellectual property have never been used by Iranian consumers. Nonetheless, the US prosecutors have shown no interest in investigating Samsung or Ericsson actively. The only presumption is that both enterprises come from American allies, whereas Huawei is associated with what is now being seen by many as America's prime adversary. ${ }^{21}$

When it comes to the trade-secret allegation, the civil lawsuit dealing with the incident was already settled in 2017. In that case, according to Huawei, T-Mobile published a video of the Tappy on YouTube, including its schematics in September 2012. As could be seen in the video, Tappy was a modified Epson SCARA robot, which was readily available. ${ }^{23}$ In other words, it could be hardly referred to as a trade secret. In addition, there was evidence showing that Tappy was not all that valuable or beneficial, since it did not work well. This point was established by the testimony of William Wevers, a third party who examined Tappy in $2012 .^{24}$

Even if the Tappy technology were effective or valuable, Huawei never incorporated it into its own robot $\mathrm{xDR}:^{25}$ it never integrated $\mathrm{xDR}$ into its testing processes; never used it to test non-T-Mobile phones; and never made changes to any phones as a result of testing with $\mathrm{xDR}$. This is why the jury awarded zero damages for trade-secret misappropriation. Since a jury has already found Huawei taking Tappy's rubber tip was not "willful and malicious," ${ }^{26}$ proving Huawei's conduct criminal "beyond a reasonable doubt" in a lawsuit will be very difficult.

This is why China initially reacted that the Americans were using their legal system to advance political interests in the ongoing contest of the two superpowers. ${ }^{27}$ Actually, the Huawei case would be a leverage for the US to urge its allies to shut Chinese companies out of their markets. However, aside from repeatedly protesting the unfair treatment by the US, the Chinese side has not done a great deal to present its side of the case. Traditionally, the Chinese views that "if one is innocent, there isn't really a need to defend oneself with words [清者自清].” Obviously, this strategy does not work well in the Western world, where Chinese 
companies have long been portrayed as 'thieves. ${ }^{28}$

The case has revealed multiple collisions of the values, concepts and culture of China and the US. Those clashes will be the dilemma of Chinese companies going global. However, the real intention behind the charges should no longer be a focus of attention in this case. Rather, Huawei needs to think seriously about how to respond to the lawsuit. In any event, local administrative and judicial systems should be respected by Chinese companies for foreign investment. All in all, it should be kept in their mind.

\section{REFERENCES}

1. US Department of Justice, Chinese Telecommunications Conglomerate Huawei and Huawei CFO Wanzhou Meng Charged With Financial Fraud, (Jan. 28, 2019), available at https:// www.justice.gov/opa/pr/chinese-telecommunications-conglomerate-huawei-and-huawei-cfowanzhou-meng-charged-financial; Chinese Telecommunications Device Manufacturer and its U.S. Affiliate Indicted for Theft of Trade Secrets, Wire Fraud, and Obstruction of Justice (Jan. 28, 2019), available at https://www.justice.gov/opa/pr/chinese-telecommunications-devicemanufacturer-and-its-us-affiliate-indicted-theft-trade (all last visited on Feb. 14, 2019).

2. During the interview with the FBI agents in July 2007, Mr. Zhengfei Ren stated that Huawei had not dealt directly with any Iranian company. See Indictment Filed in U.S. District Court E.D.N.Y. Cr. No. 18-457(S-2) (AMD) (Jan. 24, 2019) at 5, ๆๆ 13-14, available at https:// www.justice.gov/opa/press-release/file/1125021/download_(last visited on Feb. 14, 2019).

3. According to the jury's verdict, T-Mobile's breach of contract claim contained: "security costs, investigation costs, investment in testing and marketing Huawei devices, costs of finding a replacement supplier, increased costs for replacement supplies, and loss of the economic value T-Mobile derives from exclusive use of its proprietary technology." There was a bundle of issues in the breach of contract claim, including loss from trade secrets. But the jury found loss from trade secrets to be exactly zero. Although the jury awarded USD 4.8 million under the breach of contract allegation, the award does not come from the issues relating to the trade-secret claim, but from the others. See Case Document - Case No. C141351 RAJ. See also R. Lerman, Jury Awards T-Mobile \$4.8M in Trade-Secrets Case against Huawei, SeAttle Times, May 18, 2017, available at https://www.seattletimes.com/business/ technology/july-awards-t-mobile-48m-in-trade-secrets-case-against-huawei (last visited on Feb. 14, 2019).

4. See CCTV interviewed with Ren Zhengfei <available only in Chinese>, CCTV News, Jan. 21, 
2019, available at http://tech.qq.com/a/20190121/001545.htm (last visited on Feb. 14, 2019).

5. Documents show that the N.S.A. was looking to prove suspicions that Huawei was secretly controlled by China's People's Liberation Army and Mr. Ren never really left the powerful army unit. It never found the evidence, however, according to former officials. See D. Sanger, J. Barnes, R. Zhong \& M. Santora, In 5 G Race with China, U.S. Pushes Allies to Fight Huawei, N. Y. Times, Jan. 26, 2019, available at https://www.nytimes.com/2019/01/26/us/ politics/huawei-china-us-5g-technology.html?_ga=2.24317754.1001882119.1548743613171327388.1548743613 (last visited on Feb. 14, 2019).

6. See Huawei Will Struggle to Assuage Western Concerns, Fin. Times, Jan. 29, 2019, available at https://www.ft.com/content/6928451a-20d1-11e9-b126-46fc3ad87c65 (last visited on Feb. 14, 2019).

7. Yuan Yang \& Nian Liu, Huawei Founder Ren Zhengfei in His Own Words, Fin. Times, Jan. 16, 2019, available at https://www.ft.com/content/aba92826-18db-11e9-9e64-d150b3105d21 (last visited on Feb. 14, 2019).

8. Id.

9. Supra note 5.

10. Swapna Krishna, DOJ is Reportedly Investigating Huawei for Violating Iran Sanctions, ENGADGET, Apr. 25, 2018, available at https://www.engadget.com/2018/04/25/huawei-dojinvestigation-iran-sanctions (last visited on Feb. 14, 2019).

11. Supra note 5.

12. Supra note 6.

13. Supra note 5.

14. S. Gibbs, Huawei Beats Apple to Become Second-Largest Smartphone Maker, GuARDIAN, Aug. 1, 2018, available at https://www.theguardian.com/technology/2018/aug/01/huaweibeats-apple-smartphone-manufacturer-samsung-iphone (last visited on Feb. 14, 2019).

15. Supra note 5.

16. See MOFA: Gov'ts Should Not Put Unfair Pressure on Enterprises, CGTN, Jan. 28, 2019, available at https://news.cgtn.com/news/3d3d774d304d7a4d32457a6333566d54/index.html (last visited on Feb. 14, 2019).

17. Id.

18. Supra note 1.

19. According to Iran's largest Android app market Bazaar, 51\% of users have handsets produced by Samsung. Next comes to Huawei with a 32\% share. See Samsung, Huawei Dominate 83\% of Iran Android Phone Market, Fin. Tribune, Jan. 14, 2019, available at https://financialtribune.com/node/79953 (last visited on Feb. 14, 2019).

20. Ericsson confirmed it has contracts to ship and install mobile phone masts for three Iranian firms: MCCI, MTN IranCell and TCI. David Bosco, See D. Bosco, Sweden, Ericsson and Iran Sanctions, ForeIGN PoL'y, Oct. 15, 2012, available at https:/foreignpolicy.com/ 2012/10/15/sweden-ericsson-and-iran-sanctions (last visited on Feb. 14, 2019). 
21. Z. Karabell, Prosecuting the Chinese Huawei Executive is an Idiotic Way to Hold China in Check, Wash. Post, Dec. 8, 2018, available at https://www.washingtonpost.com/ outlook/2018/12/08/prosecuting-chinese-huawei-executive-is-an-idiotic-way-hold-chinacheck/?noredirect $=$ on\&utm_term $=.3 \mathrm{~d} 286 \mathrm{deb5f55}$ (last visited on Feb. 14, 2019).

22. See Say Hello to T-Mobile's Tap-Happy Device Testing Robot, Youtube (Sept. 13, 2012), available at https://www.youtube.com/watch? $\mathrm{v}=$ mv69ZxKOFSw (last visited on Feb. 14, 2019).

23. See Epson's Award-Winning Lineup of SCARA Robots, Epson, available at https://epson. com/scara-robots (last visited on Feb. 14, 2019).

24. He explained: "The T-Mobile contact area (the rubber tip) was not representative of a human finger" and the robot applied so much force that it "could actually compromise" the screen technology. See May 11 Trial Tr. at 25:8-27:20. When presented with this information, T-Mobile's own 'inventor' observed that it "reinforces the need for a rubber tip redesign." See DTX4140; DTX4145. Case Document - Case No. C14-1351, RAJ supra note 3.

25. Dr. Smith and Dr. Wolfe explained that Tappy and xDR (Huawei's own robot) were completely different in almost every respect. See May 11 Trial Tr. at 188:3-90:17,198:299:5, 205:8-206:6, 208:10-16; May 9 Trial Tr. at 198:4-199:13, supra note 3.

26. According to the criminal indictment, on May 29, 2013, Huawei (US) A.X. put the Tappy 'robot arm' into its notebook bag. A.X. then measured the size of "the stolen robot arm" and then reported it to Huawei. Interestingly, the taken part of Tappy stated in the civil case document was a 'rubber tip,' but not a 'robot arm.' It seems that the term, 'robot arm' in the criminal indictment might be an inaccurate description.

27. Supra note 21.

28. E.g., American officials assert that Huawei operated through imitation and even theft of American technology. In fact, however, Huawei did not just imitate it. It invested heavily to establish research centers (including one in California) and built alliances with leading universities around the world. It spends about $15 \%$ of its revenue on R\&D. See supra note 5 . 
